\title{
Industry sponsored youth smoking prevention programme in Malaysia: a case study in duplicity
}

\author{
M Assunta, S Chapman
}

Tobacco Control 2004;13(Suppl II):ii37-ii42. doi: 10.1136/tc.2004.007732

See end of article for authors' affiliations

....................

Correspondence to: Mary Assunta, School of Public Health, Room 129A, Edward Ford Building (A27), University of Sydney, Sydney, NSW 2006, Australia; marya@ health.usyd.edu.au

Objective: To review tobacco company strategies of using youth smoking prevention programmes to counteract the Malaysian government's tobacco control legislation and efforts in conducting research on youth to market to them.

Methods: Systematic keyword and opportunistic website searches of formerly private internal industry documents. Search terms included Malay, cmtm, jaycees, YAS, and direct marketing; 195 relevant documents were identified for this paper.

Results: Industry internal documents reveal that youth anti-smoking programmes were launched to offset the government's tobacco control legislation. The programme was seen as a strategy to lobby key politicians and bureaucrats for support in preventing the passage of legislation. However, the industry continued to conduct research on youth, targeted them in marketing, and considered the teenage market vital for its survival. Promotional activities targeting youth were also carried out such as sports, notably football and motor racing, and entertainment events and cash prizes. Small, affordable packs of cigarettes were crucial to reach new smokers.

Conclusion: The tobacco industry in Malaysia engaged in duplicitous conduct in regard to youth. By buying into the youth smoking issue it sought to move higher on the moral playing field and strengthen its relationship with government, while at the same time continuing to market to youth. There is no evidence that industry youth smoking prevention programmes were effective in reducing smoking; however, they were effective in diluting the government's tobacco control legislation.

\section{"W} e strongly believe that children should not smoke and that smoking should only be for adults who understand the risks associated with it". This statement was made by British American Tobacco (BAT) Malaysia in its first social report released in June 2002. ${ }^{1}$ Tobacco companies in Malaysia have been collaborating on youth smoking prevention programmes since $1994 .^{2}$ The top three tobacco transnationals, BAT, Philip Morris (PM), and the former RJ Reynolds (RJR), have conducted three joint anti-smoking campaigns directed at youth: "Youth Should Not Smoke" (1997); "No Sale to Under 18s" (1998); "On top of the World-Without Smoking" (2001).

The Control of Tobacco Products Regulation 1993 banned direct tobacco advertisements, the sale of cigarettes to under 18 year olds, and prohibited this group from purchasing cigarettes or smoking. However, brand stretching activities and sponsorship of sports and entertainment events remained legal and extremely widespread. ${ }^{3}$ On average, every day about 50 teenagers below the age of 18 years start smoking in Malaysia and currently about one in five teenagers smoke. ${ }^{4}$ Smoking prevalence among teenage boys aged 12-18 years is 30\% while smoking among girls has doubled from $4.8 \%$ in 1996 to $8 \%$ in $1999 .{ }^{4}$ The second national health and morbidity survey in 1996 reported the public health sector has not acted in a timely manner to curb the marketing tactics of the transnational tobacco companies and this "failure to act aggressively from the 1970s has made action in the 1990s more difficult". ${ }^{5}$ Between 1986 and 1996 there was a $67 \%$ increase in the number of teenage smokers. ${ }^{6}$ Ninety eight per cent of the tobacco market in Malaysia is controlled by transnational tobacco companies. ${ }^{7}$

In 1997 the Malaysian government fully endorsed the industry sponsored youth smoking prevention (YSP) programme. This endorsement put the tobacco industry in a favourable position to influence the government in its tobacco control efforts. While the influence of industry sponsored YSP programmes in preventing effective tobacco control legislation has already been documented, ${ }^{8-10}$ this paper provides further insight to a developing country's situation where, in the absence of a government antismoking campaign, the industry successfully used the YSP programme to counter legislation restricting tobacco marketing and continued to promote tobacco to youth.

\section{METHODS}

Data for this paper is based on tobacco industry documents searches conducted on the Master Settlement Agreement websites: www.tobaccoarchives.com. Additional searches were conducted on secondary document collection websites including Tobacco Documents Online ${ }^{11}$ and the Legacy Tobacco Documents Library. ${ }^{12}$ Initial searches conducted between November 2001 and October 2002 focused on key geographical terms representative of Malaysia such as "Malay*", "kuala lumpur", "sabah', "sarawak" and "far east" and produced 3323 documents. For details refer to: http://tobacco.health.usyd.edu.au/site/gateway/docs/pdf/ Malay Search Strategy.pdf. The results of these searches were then sorted by date and evaluated according to their degree of importance. A snowballing search strategy was then used where terms from the metadata were formulated into new search terms such as cmtm [Confederation of Malaysian Tobacco Manufacturers], yas,[young adult smokers], yams, [young adult male smokers] and direct

Abbreviations: BAT, British American Tobacco; B\&W, Brown \& Williamson; CMTM, Confederation of Malaysian Tobacco Manufacturers; JAYCEES, Junior Chambers of Malaysia; LSF, Lucky Strike Filter; MTC, Malaysian Tobacco Company; PM, Philip Morris; RJR, RJ Reynolds; YAMS, young adult male smokers; YAS, young adult smokers; YSP, youth smoking prevention 
marketing and run on the industry and secondary websites. This produced 195 documents relevant to this topic. Lack of accessibility to documents from the Guildford depository is a limitation. ${ }^{13}$

\section{RESULTS}

\section{The industry's campaign}

When tobacco control regulations to ban all direct and indirect advertisements were drafted in Malaysia in 1992, the tobacco industry responded with a plan designed to counter the regulation by proposing a youth smoking programme which would engender political and community support. The industry reasoned it could then use this programme as a sign of its sincerity to lobby key politicians and bureaucrats for support in preventing the passage of legislation it anticipated would be against its economic interests. The Confederation of Malaysian Tobacco Manufacturers (CMTM) proposed a Project "Muafakat" (consensus) where it identified several threats to the industry's "current marketing freedoms". ${ }^{14}$ To address these threats, the CMTM proposed several strategies which included political strategies "with obvious political appeal and community benefit to back up the industry and third party lobbying effort". ${ }^{14}$ Among the actions planned was one to "Develop a children and smoking programme" for government use. Link a law banning sale to under-18 year olds". ${ }^{14}$

There were three anti-smoking campaigns launched by the industry in the 1990s that reflected these plans. According to the CMTM, "Each of these campaigns has enjoyed the full cooperation of government". ${ }^{15}$ They were carried out partly in collaboration with third parties, such as the Junior Chambers of Malaysia, (JAYCEES) and endorsed by government ministries:

- "Youth should not smoke-Right decision right now" campaign (1997) in collaboration with the JAYCEES and officiated by the Minister of Education.

- "No sale to under 18s" was in collaboration with cigarette retailers and officiated by the Minister of Domestic Trade and Consumers Affairs (1998). "No sale to under-18" signage was distributed by the industry to tobacco retailers for display.

- "On top of the world-Without Smoking" campaign (2000) in collaboration with the Ministry of Youth and Sports and officiated by the minister. ${ }^{16}$

These campaigns received wide publicity: "Extensive ads appeared in all major Malaysian newspapers in support of the campaign."17 This is consistent with other findings that the industry is interested in the number of "media hits" for its YSP programmes. ${ }^{8}$

Suffering a major credibility crisis internationally tobacco companies needed to assess their positions locally. In 2000, PM Malaysia conducted a focus group study in Malaysia to assess awareness and perceptions of cigarette companies. Mirroring similar results in Australia, ${ }^{18}$ Canada, and the USA, ${ }^{19}$ a PM document on the study reported: "The tobacco industry is consistently ranked last or near last as a responsible and ethical industry. Respondents ranked the industry last because they say tobacco companies 'manufacture and sell a product hazardous to health and to the environment.' Many feel that tobacco companies are not adequately addressing problems of youth smoking."20

In an effort to redress their credibility further PM conducted more research: "To listen to the people who will define policy pertaining to smoking. To use what is learned to assist in crafting messages, actions and programs that will help position the company as a responsible corporate citizen, assist with building defenses against anti-tobacco messages,
..."21 This research showed "An overwhelming majority (about 90\%) believe that involvement in YSP [youth smoking prevention] programs is 'essential' in defining a 'responsible' tobacco company." ${ }^{21}$ It also showed the public found its efforts to curb underage purchases ineffective since "....an overwhelming $85 \%$ feel the signage has little or no effect on stopping underage sales". ${ }^{21}$

\section{The tobacco industry needs the young}

While tobacco companies publicly say children should not smoke, commercial sustainability requires that they attract young smokers, code named YAS (young adult smokers). ${ }^{22}$ PM considered youth vital in replenishing its customer base: "Young adult smokers are of primary importance for the continued growth of Marlboro." ${ }^{23}$ If this market segment erodes, the smoker base of the industry is threatened and it is "the first ring of the death bell and we therefore must come alive with gusto to correct it". ${ }^{24}$ Globally, PM established Marlboro by "Focus[ing] on the younger smoker-a key factor in the success of Marlboro advertising..."25 (emphasis in original).

Consistent with these international revelations, in Malaysia in 1992 PM reported that the strength of its Marlboro Red brand was high among young adult smokers and its consumer profile was "the youngest and most affluent". ${ }^{26}$ It was able to achieve its bottom line: "Marlboro needs to attract more starters in order to maintain its competitive edge over these brands which have a younger appeal." ${ }^{27}$ In its three year plan (1994-96) for Malaysia, PM was optimistic about good growth because of its young smokers: "Marlboro's share growth is forecasted to accelerate given its strong YAM profile, strengthening starter share, positive image and good in-switching dynamics..." ${ }^{28}$ Between 1992 and 1993, its share of smokers among the starters category had doubled. ${ }^{28}$

\section{Surveys conducted on young smokers}

For at least three decades, tobacco companies have claimed that they communicate about their cigarettes only to established smokers to maintain brand loyalty or to encourage smokers of competitors' brands to switch brands. They disavow attempting to attract new smokers or the young to start smoking. However, privately they conduct extensive surveys on starters-overwhelmingly young smokers-about their smoking behaviour to gain an understanding into why they smoke, the reasons for brand selection, their attitudes, values and lifestyles, and health concerns. ${ }^{29}$ Such research can provide some insight into why anti-smoking campaigns run by the industry are conducted in the knowledge that they will be ineffective.

Cigarette advertising directed towards young adult smokers (18-24 years) is known by the industry to be aspirational to teenagers. ${ }^{30}$ Malaysian and Singaporean research conducted for tobacco companies included "regular smokers (Malay and Chinese aged between 15 to 40 years)" ${ }^{\prime 31}$ and 16 year old smokers. ${ }^{32}$ In 1987, PM reported that their image rating for "Marlboro was relatively strong in its image as an imported brand for modern, fashionable young people; ...[respondents] gave it the highest ratings in such image attributes as (1) suitable for active people; (2) suitable for modern/fashionable people; (3) suitable for young people; (4) an imported brand; and (5) being classy/prestigious ${ }^{\prime \prime 33}$ (emphasis in original).

PM wanted to know if Marlboro was effective in appealing to starters in Malaysia and carried out a study to ascertain this information. A 1991 PM document outlines a three year market research plan for Malaysia where "The key objective is to find out whether or not Marlboro will attract smokers from the segments of starters and switchers after the launch 
of our new Marlboro campaign". ${ }^{34}$ A consultant group hired by PM in Malaysia to oversee a consumer survey in 1991 responded to a query about age of smokers with "...many Malaysian smoker [sic] start smoking earlier than 18 years old age ${ }^{\prime \prime 35}$ (emphasis in original). On this evidence, PM's $^{\prime}$

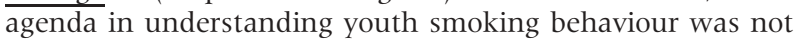
to discourage them from smoking, but rather how to make Marlboro more appealing to them.

In 1993, PM conducted a "Regional Marlboro Image Study" ${ }^{\prime \prime 36}$ in five Asian countries including Malaysia. This study was to replicate a comprehensive European study “...on the values, aspirations and lifestyles of young adult smokers (YAS), and also their views on cigarette advertising and promotions, especially Marlboro". ${ }^{36}$ The survey assessed YAM's perception of being a man: "An important social dimension to understand among Asian YAMS, given Marlboro's 'man in control' imagery, is the role of man in society. How do the YAMS view themselves as men. Is it important to be a 'male provider', how do they feel about being a man? Here we are looking to understand what it is to be masculine in the society and whether these respondents feel that it is important." ${ }^{\prime 37}$

In a follow up study, advice was given to gather information on youths' perception of American imagery: "For Marlboro we would also like to probe on its 'Americaness' and smokers' attitudes towards American cigarettes. ...What are the smokers' attitude towards small pack, their interest and possibility of switching to smaller packs. ...We need to find out:- smokers' perception of the 2 price segments - their interest and whether it affects their purchasing behaviour." 38 Teenage smokers tend to smoke less than adult smokers do. When conducting surveys on different age groups, PM factored in the lower smoking incidence among those below 18 years. ${ }^{39}$

The steady economic boom in Malaysia during the early 1990s resulted in a growing middle class with more disposable income and the emergence of a large group of modern liberal young urban Malaysians. PM in mid 1994 identified the "new YAMS values"40 associated with Malaysian youth. These comprised of "eleven value orientations described in terms of motivating dimensions" ${ }^{\prime 40}$ including "more expressions of independence \& rejection of more conservative lifestyles of parents, a desire to have their own identity and be self-determining = INDEPENDENCE" ${ }^{\prime 4}$ The Marlboro cowboy had to be presented exuding an air of "independence" to appeal to Malaysian youth. ${ }^{40}$

\section{Product development}

Prior research has established how tobacco companies developed cigarettes that used sweet taste and flavours such as chocolate, vanillin, and liquorice to appeal to young smokers. ${ }^{41}$ In Malaysia, locally manufactured cigarettes were closely monitored and coordinated by BAT's Product Policy Group. In 1990 a "modified Virginia product with vanilla sidestream" was developed for testing. ${ }^{42}$ With an eye to children's liking for sweet tasting foods, a 1993 BAT document records that sweet tasting and fruit flavoured cigarettes were to be developed for the Malaysian market: "Product team to develop new tasting cigarettes, eg. sweetened tips, taste of vanilla, strawberry and Kretek." ${ }^{13}$ In October 1993, BAT UK advised the Malaysian Tobacco Company (MTC) on measurements "...a guide on maximum level for vanilla is $1000 \mathrm{ppm}$ and for vanillin 3000ppm". ${ }^{44} \mathrm{~A}$ 1996 RJR document records how it tested and introduced Camel Filter cigarettes which gave off a "sweet/chocolate faint fruity/sour pack aroma and has a sweet, vanilla/ chocolate-like, slightly woody fruity/winey with a faint green and sour notes upon smoking" ${ }^{45}$ There is a lack of evidence to substantiate whether Malaysian youth smokers were specifically targeted; however, the experience of countries such as Singapore ${ }^{46}$ and the USA have illustrated the role of sweet taste and flavours in product development for youth smokers.

\section{Using appealing imagery to attract the young}

Tobacco companies worked closely with advertising firms to develop imagery that would appeal to the young. Consumer groups and the public health community have consistently charged the tobacco industry with using imagery attractive to young people to promote cigarettes, an allegation which the industry has denied. However, the executive director of a Malaysian advertising firm, Spencer Azizul Advertising Sdn Bhd said: "Tobacco companies are using sports, beach parties and entertainment activities as themes which have a wide appeal to the young. ...It is naïve to believe that tobacco brand advertising has no part in arousing the curiosity of the young about cigarettes or other tobacco-related products." 47 MTC, for example, used a 17 year old model to promote its "Kingsway" brand in the late 1980s. ${ }^{48}$ In 1993 PM advised the Leo Burnett agency to use in Asia "Younger, clean-shaven cowboys-Need exists to portray a more clean shaven younger image. Too much emphasis on the older, gritty look is losing its aspirational appeal". ${ }^{49}$

Tobacco companies were also aware that young smokers are health conscious ${ }^{29}$ and regard "mild" cigarettes as "less harmful". A 1985 PM document reports how Salem's growth in the Singapore, Malaysia, and Brunei markets has come mainly from young male smokers: "Salem has attracted a lot of beginners and young smokers... Salem is perceived to be milder than non-menthol cigarettes and smokers believe that menthol cigarettes are less harmful for their health. Research indicates that Salem's white tipping not only connotes mildness but it also reinforces the overall ideas of freshness in a menthol cigarette." ${ }^{\prime 50}$ The report includes a survey involving smokers as young as 16 years. RJR, the then manufacturer of Salem, described the user of Salem as someone who is "young, contemporary, stylish, pleasure seeking lifestyle" and they created "thematic advertising" to convey this image. ${ }^{51}$

\section{Marketing strategies targeting Malaysian youth}

Tobacco companies claim they do not market to children. The following are examples of marketing strategies used in Malaysia, such as sports, entertainment, cash prizes, appealing packaging, and affordable price, to appeal to youth.

\section{Sports}

Tobacco companies selected appropriate sports for sponsorship based on their popularity and youthful appeal. BAT noted: "sports have a wide popular appeal in the Far East with a youthful emphasis which helps to offset the older image/profile of the brand 555." 52 Hence, BAT sponsored table tennis, badminton, and snooker in Malaysia since these sports have "huge popular appeal". ${ }^{52}$

Malaysia's most popular spectator sport, football, has been sponsored by Dunhill between 1989 and 2004. ${ }^{53}$ The sponsorship worth US\$8 million a year ${ }^{53}$ included sponsoring major national football tournaments, telecasts of major international tournaments such as the World Cup and the European Cup, and extensive advertising for these events in the mass media. However, the tobacco industry's "On top of the world" anti-smoking campaign in 2000 featured a teenage football protégé among a few other high achieving teenagers who chose not to smoke. ${ }^{54}$ This advert, which appeared a few times in the mass media, lost impact against the bigger budget Dunhill sponsorship of football which saw more frequent advertisements promoting Dunhill sponsorship of football events and telecasts. In no other country did the 
tobacco industry use football to both promote tobacco and discourage smoking at the same time.

MTC used the tough image of motorcycles to promote its Lucky Strike brand in 1988. TV advertisements were developed although Malaysia had banned cigarette advertisements on television since 1982. It launched the Lucky Strike "biker" advertising campaign together with a "reduced price, 3 tiers below the mainstream level". ${ }^{55}$ Evaluation of this campaign revealed that "The biker himself portrayed the image of someone that was youthful, Malay, rugged, quicktempered and a show-off. It was more appealing to the Malays" ${ }^{.55}$ In 1993, another biker campaign was launched: "The Biker ads generate perceptions that coincide with the current image of Lucky Strike as a cigarette for youths/ motorcycle enthusiasts, a good quality cigarette that has style for the tough and adventurous." 56 MTC also developed an alternate fun loving imagery for Lucky Strike with "Sonst Nichts" where it sought to uplift the image of Lucky Strike "to that of youthfulness, stylishness, fun-loving, sophistication". ${ }^{56}$

As motor racing is popular with the Malaysian young, PM sponsored racing events to promote its Marlboro brand in Malaysia. A 1990 PM document reveals how it countered its competitor brand among the YAS by using motorcycle racing to promote Marlboro to the young: “To build Marlboro's image around its international motorsports involvement and to counter Lucky Strike, our most formidable competitor among the under 25's in Malaysia. ... To further capitalize on the popularity of motorcycle racing among our target group...we are sponsoring the Yamaha team which is participating in 9 races in Malaysia." ${ }^{27}$ From the "Marlboro Image Study" PM was able to establish that through the sponsorship of motor racing it was able to "reinforce Marlboro's brand personality... 'It is the same feeling you get, the tough guys at the Grand Prix and the rough, tough cowboys in the western country"'.57

\section{Entertainment}

Entertainment was the other appeal used besides sports to attract the young to cigarettes. PM notes: "While sports is by far the best avenue to attract, sample and influence our core target smokers, it's not the only way. International movies and videos also have tremendous appeal to our young adult consumers in Asia." ${ }^{27}$

BAT used music to promote its Benson \& Hedges brand as it "...has universal appeal in one form or other, can readily be tailored to suit specific markets and musical tastes, introduces youthful appeal/imagery to B\&H...creates the environment for merchandising and promotional activities". ${ }^{52}$

$\mathrm{B} \& W$ used jazz music to promote its Kool brand in Malaysia. The Malaysian subsidiary for the advertising company, KHK Needham Standard Sdn Bhd, prepared the brief for Kool: "KOOL will be positioned as the only brand for young adult trend-setters who desire the refreshing taste sensation unique to KOOL. This will be accomplished through KOOL's association with music." ${ }^{158}$ The jazz consumer profile which included teenagers was identified as “...60-70\% Malays, 15 years \& above...some students...a small but growing segment of the young, Malay educated". ${ }^{58}$

\section{Cash prizes}

In 1987, smoking increased in Malaysia compared to the previous year, particularly among young smokers. According to PM: "It was mainly attributable to the increase among young smokers between the age of 20 and 25, whose smoking incidence jumped from $13 \%$ in 1986, to $20 \%$ this year." ${ }^{\prime 33}$ The reason for the increase was a promotional campaign launched in 1987 by Rothmans and MTC where they offered M\$20 000 cash prize through Dunhill and M\$10 000 cash prize through Benson \& Hedges, respectively. On monitoring this stiff competition PM observed: "As a result of these promotional efforts, this GCS [general consumer survey] not only recorded a tremendous increase in smoker share for Dunhill, but also increases in smoking incidence, and in the trial and purchase levels of a number of brands...It attracted $62 \%$ of the beginner smokers who began to smoke during the past year." ${ }^{\prime 33}$ As for the other brands smoked by YAS, Salem recorded the highest percentage increase: "The most significant increase occurred in Salem, whose percentage of young smoker jumped from $23 \%$ of last year to $61 \%$ this year. ${ }^{133}$

\section{Packaging and affordability}

The sale of single sticks of cigarettes is legal in Malaysia. Packs containing seven sticks were also sold for as little as US $\$ 0.50$ cents. Since teenagers have less disposable income it was important for the industry to cater to young smokers with affordable cigarettes As early as 1974 BAT had noted: "In short, there seems to be a definite price block in new cigarette purchases and a definite readiness to try anything if it is given to them free." ${ }^{29}$ Free sampling was particularly effective in reaching new smokers. In a 1996 document RJR noted free sampling in Malaysia is "outlawed, but gotten around". ${ }^{59}$

The PM three year plan between 1994 and 1996 for Malaysia reveals plans to sell cheaper cigarettes and in smaller packs if young people could not afford the 20 sticks pack: "...As the total outlay for a pack of 20 's became too prohibitive for our younger adult smokers we should consider smaller packings. Currently we plan to reduce the price of our 14 's pack from $M \$ 2.40$ to $M \$ 2.20$. Should this move not yield the desired results, we will launch a 10's and 7's packing in this strong growth segment." 28

On the other hand, MTC was concerned that a cheaper cigarette could also be perceived as being of lower quality by smokers and that Lucky Strike Filter (LSF) may have that perception. It noted: “LSF's user image remains Malay, younger (20-30 years), of lower income and people just starting to smoke." ${ }^{60}$ Hence it planned to increase the price and make it appear to be a "'virtue'; to communicate to consumers that 'something has happened' with Lucky Strike" ${ }^{\prime 60}$

Menthol cigarettes were perceived to be less harmful. Combined with affordability and a suitable youthful imagery they presented a marketable formula to youth. Newport, the first menthol cigarette targeted toward the American younger adult market, ${ }^{41}$ were similarly positioned in Malaysia: "Newport's youthful U.S. image will be combined with a value for money offering in a number of markets including Singapore and Malaysia."

\section{DISCUSSION}

Although the tobacco industry in Malaysia has maintained its public stance expressing concern for youth smoking, internal documents of the industry reveal these YSP programmes were launched as gestures designed to offset the government's tobacco control legislation, which it saw as threats to its business. ${ }^{14}$ When the law to ban all direct and indirect advertising was finally passed in 1993, unlike that originally intended, it only banned direct tobacco advertisements in the mass media, leaving tobacco companies to engage freely in brand stretching or indirect advertising, sponsorship activities, and point-of-sale advertising. ${ }^{362}$ Additionally, the YSP programme was used in the attempt to strengthen its waning public credibility while framing the youth smoking issue as its platform to influence the government.

According to BAT's 2002 social report: "The problem of under-aged smoking is complex, and requires the co-operation 
and support from the government, parents, teachers and retailers to work closely with manufacturers and marketers to address."1 However, the evidence presented above illustrates tobacco companies in Malaysia have played a key role in promoting underage youth smoking. Although they deny it, underage youth are crucial to the tobacco business and the companies used strategies that encouraged smoking initiation among Malaysian teenagers. The Malaysian experience is consistent with findings documented in earlier research in other countries. ${ }^{8}$ In the 1990s BAT through the CMTM designed an authoritarian styled "Youth should not smoke" anti-smoking programme that was endorsed by the government and conducted in public schools. In the second campaign the industry had distributed authoritative styled "No sale to under 18s" signage to over 77000 retail outlets throughout the country, though the industry knew from its own consumer research ${ }^{29}$ that such gestures would be ineffective in stopping underage youth from purchasing cigarettes. Although the industry has run its campaigns since 1994, there is no evidence its YSP programme has reduced underage smoking nor prevented them from purchasing cigarettes. In fact smoking prevalence among teenagers has increased. The industry has not made public any evaluation of its YSP programmes.

While the industry addressed youth access by putting up "No sale to under $18 \mathrm{~s}$ " signage at retailers, it has not demonstrated to the public how minors obtain their cigarettes. In other nations, direct purchasing by underage youth is the most common source of cigarettes. Research into this may provide some clues to the authorities on how to address underage youth access more effectively rather than to keep endorsing retail signage as a supposedly serious means to discourage minors. Research in the USA shows there is no evidence that an increase in compliance with youth access restrictions is associated with a decrease in youth smoking prevalence. ${ }^{63}{ }^{64}$ Currently the tobacco industry in Malaysia has not made any changes to the core aspects of its business that encourage youth smoking such as the affordable price and small packaging of cigarettes. It continued to promote tobacco to youth through exemptions for sponsorship of football, ${ }^{65}$ sepak takraw (local ball game), and Formula 1. This emphasises the need to understand better the tobacco industry's own marketing research in order to design effective tobacco control campaigns as indicated in prior research. $^{66}$

Since youth smoking is of public concern, buying into this issue is designed to move the industry higher on the moral playing field ${ }^{67}$ bringing it closer to the public health community and being "part of the solution". ${ }^{54}$ In enlisting the endorsement of different ministries it strengthened its YSP programmes as well as pre-empted concerns or objections that may be raised about tobacco promotion such as tobacco sponsorship of the nation's top sports by the Youth and Sports Ministry and access and affordability of cigarettes to youth by the Trade and Domestic Trade \& Consumer Affairs Ministry. Besides, an offer to sponsor and conduct a YSP education programme in schools relieves the Education Ministry of the burden of financing and running its own programme. In the absence of government initiatives, endorsement from the ministries legitimises the industry YSP programme as the official anti-smoking education in the country. It is also to the industry's benefit to determine how youth smoking should be addressed-with ineffective programmes-so that the industry is ensured its "starters" and "YAS" base is not eroded. To that end BAT, in its social reporting programme, has proposed to continue with its media campaign, schools education programme, and retailers programme. ${ }^{1}$

\section{What this paper adds}

Earlier research has documented strategies used by tobacco companies to recruit youth smokers and the use of youth smoking prevention (YSP) programmes to obstruct tobacco control. This paper is the first to illustrate the use of YSP programmes in a developing country as a strategy to obtain political support to counter tobacco control legislation. It also illustrates how YSP programmes have not stopped tobacco companies from simultaneously promoting tobacco to youth.

In February 2004 the Malaysian government launched a RM100 million (US\$26.3 million) nationwide anti-smoking education campaign to run over five years. ${ }^{68}{ }^{69}$ This "Tak nak" (Say No) campaign has a focus on minors and calls for stricter enforcement of the law banning sales to minors. This is the first time the government has run a sustained education campaign with a significant budget. While this move is a departure from the previous industry sponsored programmes, it however appears to have similar characteristics such as "Say No" and focusing on minors.

Countries in the South East Asian region such as Thailand and Singapore, which show decreasing trends in smoking prevalence, have instituted strong tobacco control measures such as total bans on tobacco advertising and promotions, increased taxes, the banning of free sampling, as well as antismoking campaigns among youth without participation from the tobacco industry. They provide a comparison for Malaysia which lacks a national policy on tobacco control.

These experiences provide some lessons in policy for the Asian public health community:

- A national policy on tobacco control which enables an integrated, inter-ministerial approach to be taken is vital.

- Governments have little to gain from consulting with tobacco companies when drawing up tobacco control measures. Consultation presents the industry opportunities to buy time, delay government action, and water down legislation.

- Anti-smoking education is the government's responsibility. The tobacco industry should not be allowed to conduct, finance, or participate in such campaigns.

- Anti-smoking education should include both youth and adults and be part of overall comprehensive tobacco control measures that include a comprehensive ban on all forms of tobacco advertising, sponsorship, and promotional activities, a ban on smoking in public and work places, and optimum tobacco taxation.

- Cooperation is needed among neighbouring countries on cross border issues to align tobacco control measures; particularly on issues such as tobacco advertising and sponsorship activities and tobacco taxation policy.

\section{ACKNOWLEDGEMENTS}

Thanks are due to Fiona Byrne for her invaluable information management and input, and reviewers for comments. The research reported in this paper was supported by grants from the Australian National Health and Medical Research Council (2001-2003 \#153857) and the US National Institutes of Health (2001-2005 \# R01 CA87110-01Al).

\section{Authors' affiliations}

M Assunta, S Chapman, School of Public Health, University of Sydney, Sydney, NSW, Australia 


\section{REFERENCES}

British American Tobacco Malaysia. Social report. BATCo Malaysia. 2002. www. batmalaysia.com [Accessed 4 Sep 2002]

2 British American Tobacco Malaysia. Youth smoking prevention programme. BAT. 2002. http://www.batmalaysia.com [Accessed 4 Sep 2002].

3 Assunta M. Chapman S. The tobacco industry's accounts of refining indirect tobacco advertising in Malaysia. Tobacco Control 2004;13(suppl II):ii63-70.

4 World Health Organization Regional Office for the Western Pacific. Factsheet. World Health Organization Western Pacific Region Public Information Unit. 2002. http://www.wpro.who.int/public/press_release/ Press List.asp [Accessed 4 Sep 2002].

5 Padman P. Steering the young clear of nicotine addiction. The New Straits Times 31 May 1998:12. LexisNexis-All News. [Accessed 7 Jan 2003].

6 Rise in teenage smokers. The New Straits Times 21 Jun 1998: 9. LexisNexisAll News.[Accessed 7 Jan 2003].

7 Kuan M. BAT, JTI still favourites for defensive quality. The Edge 20 Mar 2003 http://www.theedgedaily.com/cms/content.jsp?id = com.tms.cms.article. Article_20234. [Accessed 11 Dec 2003].

8 Landman A, Ling PM, Glantz SA. Tobacco industry youth smoking prevention programs: protecting the industry and hurting tobacco control. Am J Public Health 2002;92:917-30.

9 Perry CL. The tobacco industry and underaged youth smoking: tobacco industry documents from the Minnesota Litigation. Arch Pediatr Adolesc Med 1999:153:935-41.

10 Hastings G, MacFadyen L. A day in the life of an advertising man: review of internal documents from the UK tobacco industry's principal advertising agencies. BMJ 2000;321:366-71.

11 Tobacco Documents Online. http://tobaccodocuments.org

12 Legacy Tobacco Documents Library. University of California, San Francisco. http://legacy.library.ucsf.edu.

13 Lee K, Gilmore AB, Collin J. Looking inside the tobacco industry: revealing insights from the Guildford Depository. Addiction 2004;99:394-97.

14 Confederation of Malaysian Tobacco Manufacturers. Project "Muafakat" business plan. 1 Sep 1992. R.J. Reynolds. Bates No. 512546460/6467. http://legacy.library.ucsf.edu/tid/apl33d00.

15 Turner C. Milk and honey. Tobacco Reporter 2000;Bonus Issue Summer: 23-25

16 Time will tell on the impact of anti puffing campaign. The Malay Mail. 8 Aug 2000:15.

17 Philip Morris International. PMI statement on prevention of youth access to cigarettes. 18 Dec 1997. Philip Morris. Bates No. 2073563052/3074A. http://legacy.library.ucsf.edu/tid/fqc95c00

18 Wirthlin Group. Australian corporate image study: general public and opinion leaders. Apr 1993. Philip Morris. Bates No. 2025837529/7579. http://legacy.library.ucsf.edu/tid/uny83e00

19 Wirthlin Group. Corporate image and issues a survey of the American public and opinion leaders. Apr 1994. Philip Morris. Bates No. 2046985503/ 5595. http://legacy.library.ucsf.edu/tid/fbi09e00

20 Philip Morris. Malaysia Focus Groups. Apr 2000. Philip Morris. Bates No. 2081751742/1743. http://legacy.library.ucsf.edu/tid/nwu65c00

21 Philip Morris. Malaysia Societal Alignment Research. Jul 2000. Philip Morris. Bates No. 2081751740/1741. http://legacy.library.ucsf.edu/tid/ mwu65c00.

22 Pittman RA. [Memorandum to J.A. Broughton et al. concerning marketing descriptors for the young smokers segment]. 24 Jan 1975. Brown \& Williamson. Bates No. 670192436. http://legacy.library.ucsf.edu/tid/ jwd14f00.

23 Philip Morris International. Marlboro worldwide creative issues and guidelines. 1990. Philip Morris. Bates No. 2501174579/4584. http:// legacy.library.ucsf.edu/tid/ook49e00.

24 Bible G. Leo Burnett meeting, Chicago September 25. 16 Sep 1992. Philip Morris. Bates No. 2504037450/7456. http://legacy.library.ucsf.edu/tid/ tnv19e00.

25 British American Tobacco Company. How Marlboro led the pack. Mar 1994 British American Tobacco. Bates No. 502570351/0387. http:// www.library.ucsf.edu/tobacco/batco/html/100/155/otherpages/ allpages.html [Accessed 4 Sep 2002]

26 Philip Morris. Marlboro Red situation analysis (Malaysia). Aug 1992. Philip Morris. Bates No. 2504052479/2489. http://legacy.library.ucsf.edu/tid/ viw19e00.

27 Philip Morris. Marlboro. 1990. Philip Morris. Bates No. 2504004484A/ 4498. http://legacy.library.ucsf.edu/tid/yuul9e00.

28 Philip Morris. Malaysia: 3 year plan 1994 to 1996. 1994. Philip Morris. Bates No. 2504033230/3262. http://legacy.library.ucsf.edu/tid/ epq19e00

29 Kenyon \& Eckhardt Advertising, Brown \& Williamson Tobacco Corporation Young adult smoker life styles and attitude. 1974. Brown \& Williamson. Bates No. 786015603/5617. http://legacy.library.ucsf.edu/tid/sds43f00.

30 ASH UK, Cancer Research Campaign. Danger! PR in the playgroundtobacco industry initiatives on youth smoking, 2000:18.

31 Survey Research Malaysia Sdn Bhd. Project Predictor II: management summary Volume I (prepared for Malaysian Tobacco Company Bhd). Mar 1984. Brown \& Williamson. Bates No. 681868961/9131. http:// legacy.library.ucsf.edu/tid/kre90fo0.

32 Tan P. Consumer Probe (S) Pte Ltd. GCS '90: age profile, 27 Sep 1990. Philip Morris. Bates No. 2504029126. http://legacy.library.ucsf.edu/tid/ dsz32e00.

33 Lok H. West Malaysia GCS 1987. 30 Dec 1987. Philip Morris. Bates No. 2504047181/7221. http://legacy.library.ucsf.edu/tid/svt19e00.
34 Philip Morris. Marketing research (Asia): 1991 three-year plan meetings. Oct 1990. Philip Morris. Bates No. 2504005657/5703. hitp:// legacy.library.ucsf.edu/tid/sjq19e00

35 Ha L. InDepth Research \& Management Consultants Sdn Bhd. [GCS Peninsular Malaysia 1991]. 22 Nov 1991. Philip Morris. Bates No. 2504029473A. http://legacy.library.ucsf.edu/tid/wfy32e00

36 So F. Regional Marlboro Image Study. 31 May 1993. Philip Morris. Bates No. 2504053181/3182. http://legacy.library.ucsf.edu/tid/ovv19e00.

37 Philip Morris. International Marlboro image dynamics study-Malaysia. Jun 1993. Philip Morris. Bates No. 2500135525/5569. http:// legacy. library.ucsf.edu/tid/bnc42e00

38 Koh A. YAMS study-Malaysia. 22 Feb 1994. Philip Morris. Bates No. 2504009191/9193. http://legacy.library.ucsf.edu/tid/ccq19e00.

39 Koh A. GCTS 1994-Malaysia. 28 Apr 1994. Philip Morris. Bates No. 2504009175/9176. http://legacy.library.ucsf.edu/tid/ecq19e00

40 HNK Asia. New YAMS values: Malaysia YAMS. Aug 1994. Philip Morris. Bates No. 2504009161/9168. http://legacy.library.ucsf.edu/tid/eia42e00

41 Wayne GF, Connolly GN. How cigarette design can affect youth initiation into smoking: Camel cigarettes 1983-93. Tobacco Control 2002; 11 (suppl I):i32-9.

42 Lee KK. Minutes of the product development team meeting held on 23rd October 1990. 1990. Brown \& Williamson. Bates No. 620457840/7846. http://legacy.library.ucsf.edu/tid/ita31fo0.

43 Hasani O. Minutes of the Product Policy Group Meeting No. 6/93 held on 27 September 1993. 27 Sep 1993. Brown \& Williamson. Bates No. 597002823/2825. http://legacy.library.ucsf.edu/tid/efd13fo0.

44 Smith G. [Fax from G. Smith to Ng Beng Sim]. 12 Oct 1993. British American Tobacco. Bates No. 110458540. http://tobacco.health.usyd.edu.au/tds/ BAT1 10458540 [Accessed 20 Oct 2002].

45 Powell RH. Malaysia; top dressing development. 26 Jun 1996. R.J. Reynolds. Bates No. 517201560. http://legacy.library.ucsf.edu/tid/sib51d00.

46 Assunta M. Chapman S. "The world's most hostile environment": how the tobacco industry circumvented Singapore's advertising ban. Tobacco Control 2004;13(suppl II):ii51-7

47 US ruling may hurt agencies. Business Times (Malaysia) 2 Jul 1997:17.

48 Ahmad A. Old pro, new act. The Star (Malaysia). 1996, http:// www.thestar.com.my/dn/personalities/19male.html [Accessed 7 Dec 2002].

49 Philip Morris. Marlboro creative brief. 23 Mar 1993. Philip Morris. Bates No. 2501084036/4039. http://legacy.library.ucsf.edu/tid/bsi49e00.

50 Tcheng J. Salem's growth in Asia. 28 Oct 1985. Philip Morris. Bates No. 2023275986/5990. http://legacy.library.ucsf.edu/tid/upw36e00.

51 Blackburn D. Malaysia/smoking population. 29 Jun 1989. R.J. Reynolds. Bates No. 516414191/4210. http://legacy.library.ucsf.edu/tid/cpy82d00.

52 British American Tobacco Company. International UK brands IBM sponsorship review - Benson \& Hedges and 555. May 1991. British American Tobacco. Bates No. 502594953/4956. http://www.moh.hnet.bc.ca/ guildford/pdf/067/00006806.pdf [Accessed 4 Sep 2002]

53 Wong J. No more million-dollar handouts to teams when Dunhill pact ends in 2004. The Star (Malaysia) 1 Jul 2002. http://www.prn2.usm.my/mainsite/ tobacco/news1.html\#no [Accessed 3 Jul 2002]

54 British American Tobacco Malaysia. Youth smoking prevention programme: on top of the world without smoking. 2002. http://www.batmalaysia.com.my [Accessed 4 Sep 2002]

55 Vasudevan B. Malaysian Tobacco Company. "Biker" research in Malaysia. 8 Sep 1993. Brown \& Williamson. Bates No. 466729618/9621. http:// legacy.library.ucsf.edu/tid/ydt43fo0.

56 Si L MTC Marketing Sdn Bhd. Biker/Sonst Nichts Oracle ad test marketing summary. 9 Sep 1993. Brown \& Williamson. Bates No. 466729644/9657 http://legacy.library.ucsf.edu/tid/eet43f00

57 Philip Morris Malaysia. Malaysia Marlboro image study. Apr 1990. Philip Morris. Bates No. 2504019106/91 18. http://legacy.library.ucsf.edu/tid/ mpa42e00.

58 KHK Needham Standard Sdn Bhd. Kool and Jazz: a proposal on parallel communications. 15 Jul 1983. Brown \& Williamson. Bates No. 670877137/ 7167. http://legacy.library.ucsf.edu/tid/aof21f00.

59 RJ Reynolds. 2.0 Market Overview. Jan 1996. R.J. Reynolds. Bates No. 523205211/5222. http://legacy.library.ucsf.edu/tid//sd51c00.

60 Miller B. Malaysia trip report. 19 Aug 1991. Brown \& Williamson. Bates No. 620447999/8004. http://legacy.library.ucsf.edu/tid/cbc31f00.

61 Brown \& Williamson Tobacco Corporation. Operational plans 1985. Nov 1984. Brown \& Williamson. Bates No. $690114497 / 4530$. http:// legacy.library.ucsf.edu/tid/lyd33foo.

62 Assunta M, Chapman S. A mire of highly subjective and ineffective voluntary guidelines: tobacco industry efforts to thwart tobacco control in Malaysia. Tobacco Control 2004;13(suppl II):ii43-50.

63 Fichtenberg CM, Glantz SA. Youth access interventions do not affect youth smoking. Pediatrics 2002;109:1088-92.

64 Goldman LK, Glantz SA. Evaluation of antismoking advertising campaigns JAMA 1998;279:772-7.

65 Assunta M. BAT flouts tobacco-free World Cup policy. Tobacco Control 2002;11:277-8.

66 Ling PM, Glantz SA. Using tobacco-industry marketing research to design more effective tobacco-control campaigns. JAMA 2002;287:2983-9.

67 Hill \& Knowlton. Philip Morris corporate affairs strategic plan for 1993. 3 Dec 1992. Philip Morris. Bates No. 2023586677/6725. http:// legacy.library.ucsf.edu/tid/oqv67e00

68 Abdullah F. Abdullah launches 'Tak nak' anti-smoking drive. New Straits Times 9 Feb 2004. http://www.nst.com.my. [Accessed 10 Feb 2004].

69 Zulfakar M. Campaign off to 'roaring' start. The Star (Malaysia) 10 Feb 2004. http://www.thestar.com.my. [Accessed 11 Feb 2004]. 